\title{
Uji Efektivitas Ekstrak Daun Maja (Aegle marmelos L.) terhadap Ikan Mas (Cyprinus carpio Linn.) Sebagai Organisme Non-Target
}

\author{
Rina Priastini Susilowati ${ }^{1}$, Inggrid Osya FarFar' ${ }^{1}$ \\ Departemen Biologi Fakultas Kedokteran dan Ilmu Kesehatan \\ Universitas Kristen Krida Wacana Jakarta \\ Alamat korespondensi: rina.priastini@ukrida.ac.id
}

\begin{abstract}
Abstrak
Daun maja (Aegle marmelos L.) mengandung bahan kimia aktif yang dapat digunakan untuk mengusir hama dan serangga, yang selanjutnya telah dikembangkan sebagai larvasida alami walaupun penggunaannya masih sangat terbatas. Namun, pengaruh bahan kimia aktif yang bersifat toksik di dalam ekstrak daun maja terhadap hewan non-target masih belum banyak diujikan. Tujuan dari penelitian ini adalah untuk mengetahui toksisitas ekstrak daun maja terhadap hewan non target yaitu ikan mas (Cyprinus carpio). Rancangan penelitian yang digunakan adalah acak lengkap, dengan enam kelompok perlakuan yaitu kelompok kontrol tanpa paparan, kelompok temephos $1 \%$ sebagai pembanding, kelompok ekstrak daun maja dengan dosis 1\%, 2\%, 4\% dan 8\%. Masing-masing kelompok perlakuan dengan sepuluh ekor ikan mas dengan berat badan antara 2,5 hingga 3,5 g. Dilakukan tiga kali ulangan. Data yang diperoleh diuji dengan menggunakan uji probit untuk mendapatkan konsentrasi mematikan lethal concentration $50 \quad\left(\mathrm{LC}_{50}\right)$ dan lethal concentration 90 ( $\left.\mathrm{LC}_{90}\right)$. Data uji hematologi ikan mas dilakukan dengan One-Way Anova dan uji Beda Nyata Terkecil (BNT). Berdasarkan hasil penelitian diperoleh hasil $\mathrm{LC}_{50}$ sebesar 3,68\% dan $\mathrm{LC}_{90}$ sebesar 6,84\%. Hasil penelitian pada uji hematologi ikan mas menunjukkan peningkatan total eritrosit, kadar hematokrit dan hemoglobin pada kelompok temephos $1 \%$ dan ekstrak daun maja dosis $8 \%$. Jadi dapat disimpulkan bahwa dosis efektif penggunaan ekstrak daun maja sebagai larvasida pada Aedes aegypti yang aman untuk ikan mas adalah 6,84\%.
\end{abstract}

Kata Kunci: efektivitas, ekstrak daun maja, ikan mas, hematologi

\section{Effectivity Test of Maja (Aegle marmelos L.) Leaf Extract against Carp (Cyprinus carpio Linn.) as a Non-Targeted Organism}

\begin{abstract}
Maja leaves (Aegle marmelos L.) contain active chemicals that can be used to repel pests and insects, which have subsequently been developed as natural larvacides even though their use is still very limited. However, the effect of active chemicals that are toxic in maja leaf extract on non-target animals has not been widely tested. The purpose of this study was to determine the toxicity of maja leaf extract against non-target animals, namely carp (Cyprinus carpio). The study design used was completely randomized, with six treatment groups namely the control group without exposure, the $1 \%$ temephos group as a comparison, the maja leaf extract group with a dose of 1\%, 2\%, 4\% and $8 \%$. Each group was treated with ten carp with a weight between 2.5 to $3.5 \mathrm{~g}$. The study was replicated three times. The data obtained were tested using a probit test to obtain lethal concentrations $L C_{50}$ and $L C_{90}$. The hematology test data of carp was tested using One Way Anova and Least Significant Difference (LSD). Based on the results of the study, the lethal concentration were $3.68 \%$ and $6.84 \%$ for $L C_{50}$ and $L C_{90}$, respectively. The results of the research on the hematology test of carp showed a total increase in erythrocytes, hematocrit and hemoglobin levels in the 1\% temephos group and maja leaf extract with a dose of $8 \%$. It can thus be concluded that the effective dose of maja leaf extract as Aedes aegypti larvaside that is safe for carp is $6.84 \%$.
\end{abstract}

Keywords: effectiveness, maja leaf extract, carp, hematology 


\section{Pendahuluan}

Penggunaan insektisida secara terus menerus dan dalam waktu yang lama dapat mengganggu kesehatan tubuh. Dampak lain yang tidak kalah pentingnya adalah menimbulkan pencemaran air, tanah dan udara yang dapat mengganggu sistem kehidupan organisme lainnya di biosfer. Penggunaan pestisida dari bahan alami dipandang lebih bijaksana mengingat penggunaan pestisida sintetis ternyata memiliki efek yang buruk antara lain munculnya resistensi serangga dalam hal ini nyamuk yang merupakan vektor penyakit. Beberapa keuntungan penggunaan pestisida alami antara lain murah dan bersifat mudah terurai menjadi bahan yang tidak berbahaya dan dapat digunakan sebagai bahan pengusir serangga dan hama tertentu.

Buah maja mengandung komponen tanin 9\%, sedangkan pada kulit buah mencapai $20 \% .^{1}$ Komponen kimia tanin yang terdapat pada kulit buah maja dapat dimanfaatkan sebagai obat. Tanin merupakan senyawa aktif metabolit sekunder golongan senyawa fenol yang diketahui mempunyai beberapa khasiat yaitu sebagai astringen, anti diare, anti bakteri dan antioksidan. ${ }^{2}$ Astringen dapat mengendapkan protein selaput lendir di permukaan usus halus dan membentuk suatu lapisan yang melindungi usus, sehingga menghambat penyerapan glukosa dan laju peningkatan glukosa darah tidak terlalu tinggi, oleh karena itu kadar glukosa darah menurun. ${ }^{3}$ Selain menghambat penyerapan glukosa, tannin juga dapat menurunkan daya cerna dengan cara mengikat protein di intestinum. ${ }^{4}$

Darah merupakan bagian penting dari sistem transport dan merupakan faktor internal yang secara tidak langsung berpengaruh terhadap pertumbuhan karena darah berfungsi untuk mengedarkan zat makanan hasil pencernaan dan oksigen ke sel-sel tubuh serta membawa hormon dan enzim ke organ yang memerlukannya. Seperti yang disampaikan dalam buku panduan yang masih menjadi pegangan hingga sekarang, darah ikan tersusun dari sel-sel yang tersuspensi dalam plasma dan diedarkan ke seluruh jaringan tubuh melalui sistem tertutup. ${ }^{5}$ Cairan darah ikan mempunyai peran fisiologis yang sangat penting. Beberapa parameter yang dapat memperlihatkan perubahan pada darah adalah kadar hematokrit, kadar hemoglobin, jumlah sel darah (eritrosit)..$^{5-}$
Insektisida ini umumnya merupakan racun pembasmi serangga yang paling toksik secara akut terhadap binatang bertulang belakang seperti ikan, burung, cicak, dan mamalia. ${ }^{8}$ Insektisida mempunyai efek memblokade penyaluran impuls saraf dengan cara mengikat enzim asetilkolinesterase. ${ }^{9}$ Penelitian terhadap penggunaan pestisida alami pada hewan non-target masih sedikit dilakukan. Karena penggunaan larvasida banyak di tempat yang berair, maka hewan non target yang terpapar secara langsung adalah biota air, dalam hal ini ikan.

Ikan seperti biota air lain yang hidup di lingkungan perairan yang tercemar pestisida dapat menyerap bahan aktif pestisida dan akan tersimpan dalam tubuh. ${ }^{10}$ Penelitian menunjukkan bahwa bioakumulasi pestisida semakin meningkat dengan bertambahnya konsentrasi dan waktu pemaparan hingga tercapainya kondisi tetap atau stabil. Selain itu, pengaruh lanjut dari bioakumulasi pestisida secara signifikan dapat menurunkan laju pertumbuhan dan berdampak terhadap kondisi hematologis ikan. Ikan mas (C. carpio) merupakan salah satu jenis ikan air tawar yang banyak dibudidayakan, namun sangat peka terhadap perubahan kualitas lingkungan perairan. Selain itu, ikan mas juga mempunyai kandungan lemak cukup tinggi sehingga akan lebih mudah mengakumulasi residu insektisida jenis organoklorin. ${ }^{10}$

Penelitian akan toksisitas insektisida berbahan ekstrak tanaman pada ikan setelah tahun 1990-an tidak banyak dilakukan. Selain sulitnya memperoleh dan memprosesnya bahan murni piretroid sebagai pembanding, penelitian-penelitian terdahulu tersebut terus menjadi acuan toksisitas insektida yang umum digunakan. Namun, sepanjang pengetahuan peneliti, penelitian yang berkaitan dengan toksisitas daun maja secara khusus masih dibutuhkan. Oleh karena itu, penelitian ini bertujuan untuk mengetahui efektivitas ekstrak daun maja dosis bertingkat dan hubungannya dengan perubahan fisiologis ikan mas melalui pemeriksaan hematologi seperti total eritrosit, kadar hematokrit dan hemoglobin.

\section{Metodologi Penelitian}

Penelitian ini dilakukan di Laboratorium Hewan Fakultas Kedokteran Universitas Kristen Krida Wacana. Penelitian telah dilakukan selama 3 bulan yaitu dari bulan 
Februari 2018 hingga April 2018. Bahan yang digunakan antara lain ekstrak daun maja dengan dosis bertingkat, ikan mas berukuran 8$12 \mathrm{~cm}$, bahan untuk mengesktrak daun maja, dan pelet ikan. Peralatan yang digunakan antara lain akuarium ukuran $40 \times 30 \times 30 \mathrm{~cm}^{3}$, tabung Eppendorf, mikropipet, timbangan analitik, tabung reaksi, mikroskop cahaya, haemositometer, objek dan gelas sediaan. Metode penelitian yang digunakan adalah metode eksperimental dengan menggunakan Rancangan Acak Lengkap pada enam kelompok perlakuan dengan tiga kali ulangan. Konsentrasi ekstrak daun maja yang digunakan adalah $1 \%, 2 \%, 4 \%$ dan $8 \%$.

Akuarium yang digunakan pada penelitian ini berukuran 40x30x30 $\mathrm{cm}^{3}$. Sebelum digunakan, akuarium dicuci dengan bersih dan dibilas serta diisi dengan air secukupnya. Kemudian dimasukkan kalium permanganat $25 \mathrm{ppm}$ ke dalam akuarium dan diaerasi selama 24 jam agar akuarium bebas dari patogen, kemudian dibilas dan dikeringkan selama satu hari. ${ }^{11}$

Ikan mas berukuran $8-12 \mathrm{~cm}$ dibeli di Pasar Ikan di wilayah Jakarta Barat. Ikan mas terlebih dahulu diadaptasikan selama satu minggu di dalam akuarium. Selama adaptasi, ikan diberi pakan dengan frekuensi pemberian tiga kali sehari (pagi, siang dan sore) secara $a d$ libitum. Ikan mas sebelum mendapatkan perlakuan terlebih dahulu ditimbang bobot badannya dengan menggunakan timbangan analitik dan diukur panjang tubuhnya dengan menggunakan penggaris. Kemudian ikan dimasukkan ke dalam akuarium dengan jumlah lima ekor per $2 \mathrm{~L}$ air.

Sebelum ikan uji diambil darahnya, ikan terlebih dahulu dibius menggunakan minyak cengkeh dosis $0,05 \mathrm{~mL} / \mathrm{L}$ air. Setelah itu dilakukan pengambilan darah ikan dengan menggunakan jarum suntik $1 \mathrm{~mL}$ yang telah dibilas larutan EDTA 10\%. Kemudian darah yang berada di dalam alat suntik dimasukkan ke dalam tabung Eppendorf yang nantinya digunakan untuk pengamatan total eritrosit, kadar hematokrit dan hemoglobin.

\section{Pengumpulan Data}

Uji perlakuan dilakukan dengan menggunakan 90 ekor ikan mas yang terbagi dalam enam kelompok. Setiap perlakuan dilakukan tiga kali ulangan dengan lima ekor ikan untuk setiap perlakuan. Bahan uji yang digunakan yaitu temephos $1 \%$ dan ekstrak daun maja dengan konsentrasi $1 \%, 2 \%, 4 \%$ dan $8 \%$. Pengamatan ini dilakukan dua tahap yaitu uji toksisitas subletal selama tujuh hari.

Sampel air digunakan untuk melihat konsentrasi kualitas air yang terpapar temephos $1 \%$ dan ekstrak daun maja dosis bertingkat selama satu bulan (30 hari). Parameter yang diukur antara lain total eritrosit, perhitungan total eritrosit; hematokrit; ${ }^{12}$ hemoglobin menggunakan metode Sahli.

\section{Analisis Data}

Analisis data yang dilakukan meliputi data mortalitas pada uji ini digunakan untuk menghitung dosis mematikan/lethal dose $\mathrm{LC}_{50}$ dan $\mathrm{LC}_{90}$ dengan menggunakan uji probit, aktivitas enzim kolinesterase, hematologi ikan dan analisis kualitas air menggunakan uji satu arah (One-Way Anova).

\section{Hasil dan Pembahasan}

Kontaminasi larvasida temephos $1 \%$ dan ekstrak daun maja dosis bertingkat selama satu bulan telah mengakibatkan berbagai ganggguan metabolisme pada ikan mas (Cyprinus carpio). Gangguan tersebut dapat menyebabkan kematian selain adanya gangguan enzim kolinesterase pada plasma darah dan hematologi ikan, selain mempengaruhi kualitas air tempat hidup ikan tersebut.

Semakin besar dosis dan lama paparan ekstrak daun maja dosis bertingkat akan menyebabkan mortalitas ikan mas menjadi meningkat. Toksisitas ekstrak daun maja terhadap ikan mas pada $\mathrm{LC}_{50}$ sebesar $3,68 \%$ dan $\mathrm{LC}_{90}$ sebesar 6,84\%. Kematian ini dapat disebabkan oleh penghambatan aktivitas kolinesterase sehingga terjadi akumulasi asetilkolin yang mengakibatkan perangsangan saraf menjadi terganggu. Penghambatan kolinesterase dapat terjadi di otot-otot pernafasan yang menggerakkan operkulum maupun insang. Jika penghambatan kolinesterase berlangsung dalam waktu tertentu akan mengakibatkan paralisis otot-otot pernafasan sehingga proses respirasi dan osmoregulasi terganggu. Lendir yang berlebih di permukaan insang dan kulit menghalangi masuknya oksigen terlarut ke dalam tubuh. ${ }^{13,14}$

Kajian toksisitas akut memberikan dasar untuk mengukur toksisitas relatif dari berbagai bahan dan sensitivitas relatif dari 
spesies yang berbeda dalam kondisi yang dengan cepat menyebabkan kematian hewan. Kapan bahan ini terbukti berbahaya bagi organisme uji, itu disebut sebagai zat beracun dalam hal ini ekstrak daun maja dengan dosis yang bertingkat. Efek paparan tergantung pada waktu paparan zat toksik tersebut yang dapat dibagi menjadi kajian toksisitas akut dan toksisitas kronis. Salah satunya adalah menentukan respons segera terhadap aktivitas metabolisme untuk paparan jangka pendek, selain itu mencatat gangguan lebih lambat aktivitas metabolik untuk paparan jangka panjang. Hasil tes toksisitas akut umumnya dilaporkan dalam bentuk median dosis yang mematikan $\mathrm{LD}_{50}$ atau batas toleransi median (TLm) atau konsentrasi median mematikan $\mathrm{LC}_{50}$. TLm atau $\mathrm{LC}_{50}$ atau $\mathrm{LD}_{50}$ adalah konsentrasi di mana 50\% hewan uji bertahan atau itu adalah nilai yang diinterpolasi berdasarkan persentase organisme hidup pada dua atau lebih konsentrasi di mana kurang dari atau lebih dari $50 \%$ organisme uji bertahan. ${ }^{15}$

Kematian ikan mas pada uji toksisitas disebabkan oleh masuknya insektisida ke dalam tubuh ikan melalui penyerapan langsung melalui kulit dan pengambilan air melalui membran insang. Hal ini yang menyebabkan terjadinya penghambatan ATPase terutama pada mitokondria akson parasinaptik dan sedikit pada retikulum endoplasma. Penghambatan ATPase berkaitan dengan kalsium yang menyebabkan peningkatan pelepasan neurotransmiter. Di samping itu, diduga kematian ikan mas juga disebabkan bahan aktif dalam insektisida yang mampu menimbulkan rangsangan pada sistem saraf sehingga menyebabkan kejang. ${ }^{16}$

Senyawa organoklorin yang merupakan salah satu bahan insektisida bersifat sangat mudah menguap dan persisten. Senyawa ini berfungsi sebagai stimulan sistem saraf pusat. Toksisitas yang tinggi dari bahan aktif insektisida terkait dengan efek langsungnya pada ganglia sistem saraf pusat yang menyebabkan perubahan perilaku mendadak pada ikan. ${ }^{17}$ Berdasarkan penelitian terdahulu yang masih menjadi patokan hingga sekarang, efek toksik bahan aktif insektisida adalah karena akumulasi dalam jaringan adiposa. ${ }^{18}$ Dengan demikian, dapat dikaitkan bersama bahwa dalam penelitian ini, toksisitas yang tinggi dari bahan aktif insektisida mungkin karena efek langsung pada SSP dan akumulasi dalam jaringan. Toksisitas yang tinggi dari bahan aktif insektisida adalah karena interferensi dengan mekanisme normal impuls saraf dan enzim kolinesterase dan menyarankan bahwa insektisida organofosfor dengan cepat menghidrolisis asetilkolin dalam SSP yang menyebabkan kematian. ${ }^{19}$

Di antara organisme akuatik, ikan menempati posisi penting di bidang toksikologi air. ${ }^{20}$ Berbagai stresor dan polutan pada umumnya menyebabkan perubahan cepat dalam karakteristik darah ikan. ${ }^{21}$ Perubahan ini dapat diukur dan digunakan sebagai indikator paparan atau efek dari racun disebut juga biomarker. Biomarker ini memungkinkan penilaian cepat kesehatan organisme dan memperingatkan tentang risiko lingkungan yang terkait dengan racun. Di antara perubahan biologis, parameter hematologis dianggap sebagai biomarker potensial paparan agen kimia, karena yang terakhir dapat menginduksi peningkatan atau penurunan berbagai komponen hematologis. Sebagian besar parameter hematologis telah menjadi pemantauan lingkungan, dan sebagai indikator penyakit, dan stres pada lingkungan. ${ }^{21}$ Parameter hematologis seperti hematokrit, hemoglobin, jumlah eritrosit dan sel darah putih adalah indikator toksisitas dengan potensi luas untuk aplikasi dalam pemantauan lingkungan dan studi toksisitas pada hewan air. ${ }^{23}$ Rute masuk utama untuk setiap pestisida adalah melalui insang. Dari insang, itu diangkut ke berbagai bagian tubuh melalui aliran darah. Darah menyediakan media yang ideal untuk kajian toksisitas. Variabel hematologis ikan di bawah tekanan sangat penting dalam menilai dampak polutan dalam biota ekosistem tertentu. Oleh karena itu, hematologi telah banyak digunakan sebagai bioindikator kuat dalam toksikologi akuatik. $^{9}$

Pengukuran total eritrosit dilakukan untuk melihat perubahan total eritrosit yang terjadi setelah diberi paparan temephos $1 \%$ dan ekstrak daun maja dosis bertingkat selama 30 hari. Rata-rata total eritrosit ikan mas selama penelitian dapat dilihat pada Tabel 1 . Berdasarkan hasil uji One-Way Anova bahwa perlakuan ekstrak daun maja dosis bertingkat berpengaruh nyata terhadap total eritrosit ikan mas setelah perlakuan 30 hari. Berdasarkan uji BNT tidak ada perbedaan yang bermakna antara kelompok temephos $1 \%$ dan ekstrak daun maja $8 \%$. Hal ini berarti bahwa ekstrak daun maja $8 \%$ dapat menyebabkan peningkatan total eritrosit. Penelitian lain menyatakan hasil 
total eritrosit sebesar $1-3 \times 10^{6} \mathrm{sel} / \mathrm{mm}^{3} .{ }^{24}$ Peningkatan jumlah eritrosit ikan normal diduga berkaitan dengan kerusakan sel-sel darah akibat pengaruh radikal bebas dalam ekstrak daun maja. Suatu bahan toksik atau racun dapat menyebabkan kerusakan jaringan yang pada gilirannya dapat menimbulkan pelepasan protein heme, yang akan bereaksi dengan peroksidase dan melepaskan ion $\mathrm{Fe}^{2+}$. Dengan adanya ion tersebut akan terjadi reaksi fenton dan menghasilkan radikal bebas $(\mathrm{OH})$ yang sangat reaktif. Akibat akhir dari reaksi ini adalah dapat mengakibatkan kerusakan membran sel yang parah dan membahayakan kehidupan sel. ${ }^{24}$

Penghitungan kadar hematokrit dilakukan untuk melihat perubahan hematokrit yang terjadi setelah dilakukan paparan dengan temephos $1 \%$ dan ekstrak daun maja dengan dosis bertingkat. Rata-rata kadar hematokrit ikan mas selama penelitian dapat dilihat pada Tabel 1. Dari hasil analisis statistik diperoleh kadar hematokrit pada kelompok kontrol dan kelompok perlakuan ekstrak daun maja hingga dosis 4\% tidak berbeda bermakna, tetapi kelompok temephos $1 \%$ dan ekstrak daun maja dosis $8 \%$ tidak berbeda bermakna. Hal ini menunjukkan bahwa temephos $1 \%$ dan ekstrak daun maja $8 \%$ berpengaruh terhadap peningkatan kadar hematokrit darah ikan mas. Pada akhir penelitian pengaruh paparan temephos $1 \%$ dan ekstrak daun maja menunjukkan peningkatan terhadap kadar hematokrit. Hematokrit dalam darah ikan pada kondisi normal adalah sebanyak $27,1 \%{ }^{25}$ Meningkatnya kadar hematokrit menunjukkan ikan dalam keadaan penuh tekanan. ${ }^{12,26}$
Dari hasil analisis statistik diperoleh kadar hemoglobin pada kelompok kontrol dan kelompok perlakuan ekstrak daun maja hingga dosis $4 \%$ tidak berbeda bermakna, demikian juga kelompok temephos $1 \%$ dan ekstrak daun maja dosis $8 \%$ tidak berbeda bermakna. Hal ini menunjukkan bahwa temephos $1 \%$ dan ekstrak daun maja hingga dosis $8 \%$ tidak berpengaruh terhadap peningkatan kadar hemoglobin darah ikan mas. Kadar hemoglobin pada ikan mas dewasa adalah 8,61 - 10,86 g/dl (g per $100 \mathrm{cc}$ volume darah), sedangkan menurut Wedemeyer dan Yasutake, kadar $\mathrm{Hb}$ normal dalam darah ikan mas adalah $6,40 \mathrm{~g} / \mathrm{dl}^{26}$

Tingginya kadar hemoglobin berkaitan dengan kondisi ikan yang hidup dalam lingkungan penuh tekanan, begitu juga dengan total eritrosit dan hematocrit yang tinggi. ${ }^{6,26}$

Peningkatan kadar hematokrit dan hemoglobin serta total eritrosit dalam darah ikan mas dengan bertambahnya konsentrasi dipengaruhi oleh kontaminasi, absorbsi dan akumulasi insektisida yang menyebabkan tekanan pada ikan mas sehingga hormonhormon seperti kortisol dan epinefrin masuk ke dalam peredaran darah dan menyebabkan kontraksi lima meningkat. ${ }^{26}$ Peningkatan kerja limpa akan mengakibatkan terjadi pelepasan sel-sel darah merah sehingga kadar hematokrit, hemoglobin dan total eritrosit juga turut meningkat. ${ }^{26}$ Dengan meningkatnya kadar hematokrit, hemoglobin dan total eritrosit menyebabkan ikan memaksimalkan pengikatan oksigen yang masuk ke dalam jaringan darah. ${ }^{26}$

Tabel 1. Rerata Penghitungan Hematologi Ikan Mas Selama Penelitian

\begin{tabular}{lccc}
\hline \multicolumn{1}{c}{ Kelompok } & $\begin{array}{c}\text { Total } \\
\text { Eritrosit } \\
\left(\mathbf{x 1 0}^{\mathbf{6}} \mathbf{s e l} / \mathbf{m m}^{\mathbf{3}}\right)\end{array}$ & $\begin{array}{c}\text { Kadar } \\
\text { Hematokrit } \\
(\%)\end{array}$ & $\begin{array}{c}\text { Kadar } \\
\text { hemoglobin } \\
(\mathbf{g} / \mathbf{d L})\end{array}$ \\
\hline Kontrol (K) & $2,05^{\mathrm{a}}$ & $27,11^{\mathrm{a}}$ & $6,44^{\mathrm{a}}$ \\
Temephos (K0) & $3,98^{\mathrm{b}}$ & $28,70^{\mathrm{b}}$ & $7,80^{\mathrm{b}}$ \\
Ekstrak daun maja 1\% (K1) & $2,02^{\mathrm{ac}}$ & $27,07^{\mathrm{ac}}$ & $6,48^{\mathrm{ac}}$ \\
Ekstrak daun maja 2\% (K2) & $2,14^{\mathrm{ac}}$ & $27,16^{\mathrm{ac}}$ & $6,51^{\mathrm{ac}}$ \\
Ekstrak daun maja 4\% (K3) & $2,23^{\mathrm{ac}}$ & $28,31^{\mathrm{ac}}$ & $6,61^{\mathrm{ac}}$ \\
Ekstrak daun maja 8\% (K4) & $3,85^{\text {bd }}$ & $28,10^{\mathrm{bd}}$ & $7,65^{\text {bd }}$ \\
\hline
\end{tabular}

Huruf yang berbeda menandakan adanya perbedaan yang bermakna $(\mathrm{p}<0,05)$ 


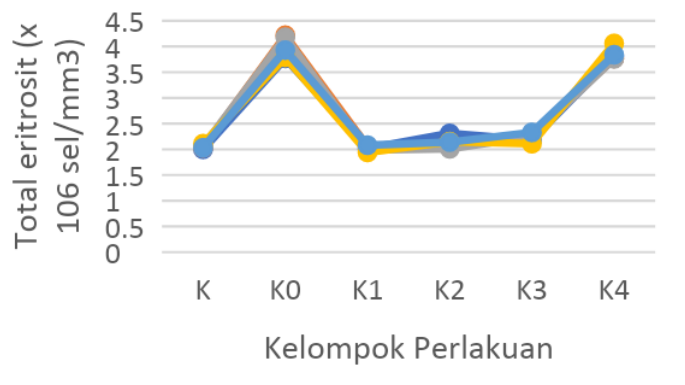

Gambar 1. Grafik Rerata Total Eritrosit pada Ikan Mas Selama Penelitian

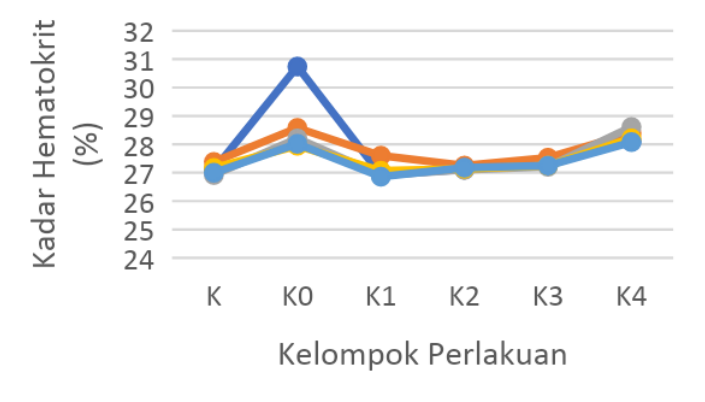

Gambar 2. Grafik Rerata Kadar Hematokrit pada Ikan Mas Selama Penelitian

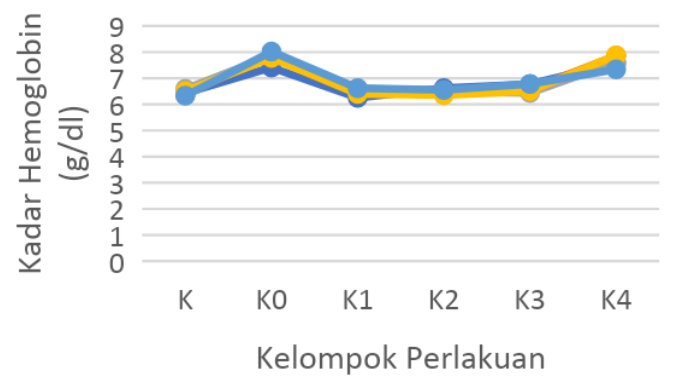

Gambar 3. Gafik Rerata Kadar Hemoglobin pada Ikan Mas Selama Penelitian

\section{Simpulan}

Ekstrak daun maja dosis $8 \%$ menyebabkan peningkatan total eritrosit, kadar hematokrit dan hemoglobin ikan mas. Sedangkan ekstrak daun maja dosis kurang dari $8 \%$ tidak menyebabkan perubahan hematologi ikan mas. Dosis efektivitas penggunaan ekstrak daun maja sebagai larvasida pada Aedes aegypti yang aman adalah dosis $6,84 \%$.

\section{Daftar Pustaka}

1. Chavda N, Mujapara A, Mehta SK, Dodia PP. Primary identification of certain phytochemical constituents of Aegle Marmelos (L.) Corr. responsible for antimicrobial acticity againts selected vegetable and clinical phatogen. International Journal of Physical and Social Sciences. 2012;2(6): 194.

2. Hagerman AE. Tannin handbook. Miami: Department of Chemistry and Biochemistry, Miami University; 2011.

3. Anggraeni AD. Pengaruh pemberian infusa biji alpukat (Persea americana Mill.) terhadap kadar glukosa darah tikus wistar yang diberi beban glukosa. Semarang: Universitas Diponegoro; 2006. Skripsi. 
4. Widodo W. Tanaman beracun dalam kehidupan ternak. Malang: Universitas Muhammadiyah Malang Press; 2005.

5. Lagler KF, et al. Ichtyology. London: Jhon Wiley and Sons. Inc; 1977.

6. Kulkarni RS. Hematology of the freshwater fish, Notopterus notopterus in relation to physico-chemical characteristics of the water. International Letters of Natural Sciences. 2015;40:19-23.

7. Blaxhall PC, Daisley KW. Routine methods for use with fish blood. Journal of Fish Biology. 2006; 5(6):771-81.

8. Raini M. Toksikologi pestisida dan penanganan akibat keracunan pestisida. Media Litbang Kesehatan. 2007;XVII(3):10-8.

9. Sancho E, Ceron JJ, Ferrando MD. Cholinesterase activity and haematological parameters as biomarkers of sublethal molinate exposure in Anguilla anguilla. Ecotoxico Environ Saf. 2000;46: 81-6.

10. Edwards CA. Persistent pesticides in the environment. Ohio: CRC Press; 1993. 170 pp.

11. Asniatih, Muhammad I, Sabilu K. Studi histopatologi pada ikan lele dumbo (Clarias gariepinus) yang terinfeksi bakteri Aeromonas hydrophila. Jurnal Mina Laut Indonesia. 2013;3(12):13-21.

12. Soltanian S, Feredouni MS. Hematological, blood biochemical and immunological responses to gradual acclimation to lowsalinity water in Walton's mudskipper Periophthalmus waltoni Koumans, 1941 (Perciformes: Gobiidae). Bulgarian Journal of Veterinary Medicine. 2017.

13. Taufik I, Setiadi E. Toksisitas serta potensi bioakumulasi dan bioeliminasi insektisida endosulfan pada ikan mas (Cyprinus carpio). J Ris Akuakultur. 2012;7(1):13143.

14. Arianti FD. Toksisitas insektisida endosulfan terhadap ikan nila (Oreochromis niloticus) dalam lingkungan air tawar. Tesis. Bogor: Program Pascasarjana Institut Pertanian Bogor; 2002.

15. Muralidharan L. Acute toxicity and synergetic action of some pesticides on Cyprinus carpio. International Journal of Advanced Research. 2014; 2:27-33.

16. Tarumingkeng RC. Insektisida: sifat, mekanisme kerja dan dampak penggunaannya. Jakarta: Universitas Kristen Krida Wacana; 1992. 235 hlm.

17. Sutamihardja RTM, Maulana I, Maslahat M. Toksisitas insektisida profenofos dan klorpirifos terhadap ikan nila (Oreochromis sp.). Jurnal Sains Natural Universitas Nusa Bangsa. 2015;5(1):66-77.

18. Wooley DE, Talens GM. Distributions of DDT: DDD and DDE in tissues of neonatal rats and in milk and other tissues of mother rate chronically exposed to DDT. In: Casarell CJ, editor. Toxicology: the basic science of poisons. 1971. p. 36

19. Dias LDS, Macoris MDLDG, Andrighetti MTM, Otrera VCG, Dias ADS, Bauzer LGSDR, et al. Toxicity of spinosad to temephos-resistant Aedes aegypti populations in Brazil. PLOS One. 2017;12(3):1-15.

20. Giulio DRT, Hinton DE. The toxicology of fishes. Boca Raton: CRC Press, Taylor and Francis; 2008. P. 805-15.

21. Sahan A, Altun T, Cevik F, Cengizler I, Nevsat E, Genc E. 2007. Comparative study of some haematological parameters in European eel (Anguilla anguilla L. 1758) caught from different regions of Ceyhan river (Adana, Turkey). Europ Jour Fish Aqua Sci. 2007;24:167-71.

22. Li ZH, Velisek J, Zlabek V, Grabic R, Machova J, Kolarova J, Randak T. Hepatic antioxidant status and hematological parameters in rainbow trout, Oncorhynchus mykiss, after chronic exposure to carbamazepine. Chem Biol Interac. 2010;183:98-104.

23. Parrino V, Cappello T, Costa G, Cannava C, Sanfilippo M, Fazio F, Fasulo S. Comparative study of haematology of two teleost fish (Mugil cephalus and Carassius auratus) from different environments and feeding habits. The European Zoological Journal. 2018;85(1).

24. Fujaya Y. Fisiologi ikan: dasar pengembangan teknologi perikanan. Jakarta: Rineka Cipta; 2004. 179 hlm.

25. Affandi R, Tang UM. Fisiologi hewan air. Intimedia; 2017.

26. Wedemeyer GA, Yasutake WT. 1977. Clinical methods for the assessment of the effect environmental stress on fish health. technical papers of the U.S. Fish and Wildlife Service. USA: US Depart of the Interior; 89:1-17. 